\title{
Perancangan Turbin Angin Vertikal Modifikasi Gabungan Savonius dan Darrieus Menggunakan Geometri NACA 0018
}

\section{The Design of a Modified Vertical Wind Turbine Combined with Savonius and Darrieus Uses Geometry NACA 0018}

\author{
Rahmad Samosir ${ }^{1}$, Medyawanti Pane ${ }^{2 *}$, Joko Herman Lumbantoruan ${ }^{3}$ \\ 1,2,3 Universitas Kristen Indonesia
}

Diterima: 05-08-2020 ; Disetujui: 23-02-2021 ; Diterbitkan: 06-05-2021

*Corresponding author E-mail: medyawanti.pane@uki.ac.id

\begin{abstract}
Abstrak
Desain gabungan antara modifikasi Savonius dan modifikasi Darieus (menggunakan geometri airfoil NACA 0018) dirancang memanfaatkan kecepatan angin rendah yang akan di konversi menjadi energi listrik alternatif sehingga dapat dimanfaatkan untuk rumah tangga dan komersil. Dikarenakan kedua jenis turbin ini memiliki kelebihan dan kekurangan masing-masing, maka dirancang pengabungan dari modifikasi kedua turbin ini yang mampu memberikan daya yang lebih besar. Pada kecepatan yang sama yaitu 6,1 m/s dilakukan pengujian dan diperoleh daya yang dihasilkan oleh turbin modifikasi Savonius ialah 3,32 Watt dan daya yang dihasilkan oleh turbin modifikasi Darrieus ialah 14,62 Watt, sementara daya yang dihasilkan oleh turbin modifikasi gabungan lebih tinggi yaitu17,86 Watt. Dari hasil tersebut dapat disimpulkan bahwa turbin modifikasi gabungan 1,2 kali lebih besar dari modifikasi Darieus, dan daya yang dihasilkan oleh turbin modifikasi gabungan 5,38 kali lebih besar dari modifikasi Savonius. Sementara koefisien daya dihasilkan oleh turbin modifikasi gabungan 1 kali lebih besar dari modifikasi Darieus, dan koefisien daya yang dihasilkan oleh turbin modifikasi gabungan 5,05 kali lebih besar dari modifikasi Savonius. Sehingga penggabungan modifikasi turbin Darieus-Savonius pada satu poros dapat meningkatkan efisiensi dalam mengkonversi energi angin menjadi daya listrik.
\end{abstract}

Kata Kunci: NACA 0018, Gabungan Savonius Darieus, Turbin Angin Vertikal

\begin{abstract}
The combined design of the Savonius modification and the Darieus modification (using the NACA 0018 airfoil geometry) is designed to utilize wind speeds that will be converted into electrical energy that can be used for household and commercial use. Because these two types of turbines have their own advantages and disadvantages, the combination of these two turbines is designed to provide greater power. At the same speed of $6.1 \mathrm{~m} / \mathrm{s}$ the test was carried out and the power produced by the Savonius modified turbine produced 3.32 Watt and the power generated by the modified Darrieus turbine is 14.62 Watt, while the power produced by the modified turbine modification is higher at 17.86 Watt. From these results it can be concluded that the combined modification turbine is 1.2 times greater than the modified Darieus, and the power produced by the combined modified turbine is 5.38 times greater than the Savonius modification. While the power coefficient produced by the combined modification turbine is 1 times greater than the Darieus modification, and the power coefficient produced by the combined modification turbine is 5.05 times greater than the Savonius modification. So that the incorporation of the Darieus-Savonius turbine modification on one axis can improve efficiency in converting wind energy to electrical power.
\end{abstract}

Keywords: NACA 0018, Combined Savonius Darieus, Vertical Wind Turbine.

How to Cite: Samosir, R., 2021, Perancangan Turbin Angin Vertikal Modifikasi Gabungan Savonius dan Darrieus Menggunakan Geometri NACA 0018, JMEMME Uournal of Mechanical Engineering, Manufactures, Materials and Energy), 5 (1): 69-77 
Samosir, R., Perancangan Turbin Angin Vertikal Modifikasi Gabungan .....

\section{PENDAHULUAN}

Secara umum kincir angin terdiri dari kincir angin poros horizontal dan vertical [1] [2] [3] seperti yang ditunjukkan oleh gambar 1.

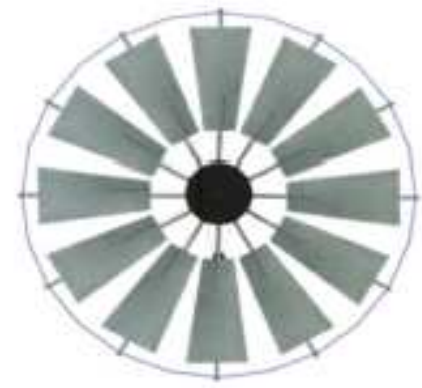

(a)
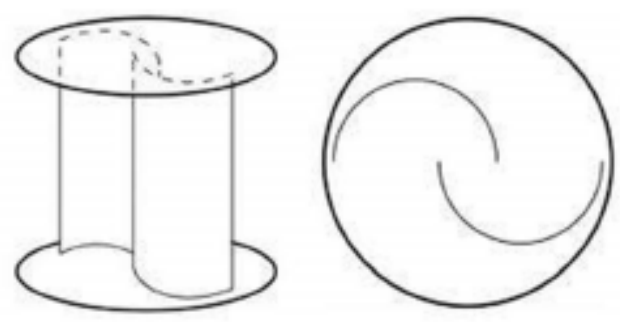

(b)

Gambar 1. (a) Kincir angin dengan poros horizontal, (b) Kincir angin dengan poros vertikal

Turbin angin sumbu horizontal lebih efektif dalam mengekstrak energi angin dibanding dengan turbin angin sumbu vertikal. namun, turbin angin vertikal memiliki keunggulan yaitu Turbin angin sumbu vertikal tidak harus diubah posisinya jika arah angin berubah, tidak seperti turbin angin horizontal yang memerlukan mekanisme tambahan untuk menyesuaikan rotor turbin dengan arah angin, dan konstruksi turbin yang sederhana dan tidak membutuhkan menara yang tinggi serta dapat beroperasi pada kecepatan angin rendah yang memungkinkan turbin angin jenis vertikal sangat cocok dengan keadaan di Iklim Indonesia [4] [5] [6].

Prinsip kerja dari rotor Darrieus diasumsikan arah angin datang dari depan rotor baling-baling. Ketika pergerakan rotor lebih cepat menyamai dengan kecepatan angin yang tak terganggu yaitu ratio kecepatan blade dengan kecepatan angin bebas, TSR> 3 . Gambar 2 menunjukan garis vektor percepatan dari bentuk airfoil baling-baling pada posisi angular yang berbeda-beda [3] [7] [8]. 


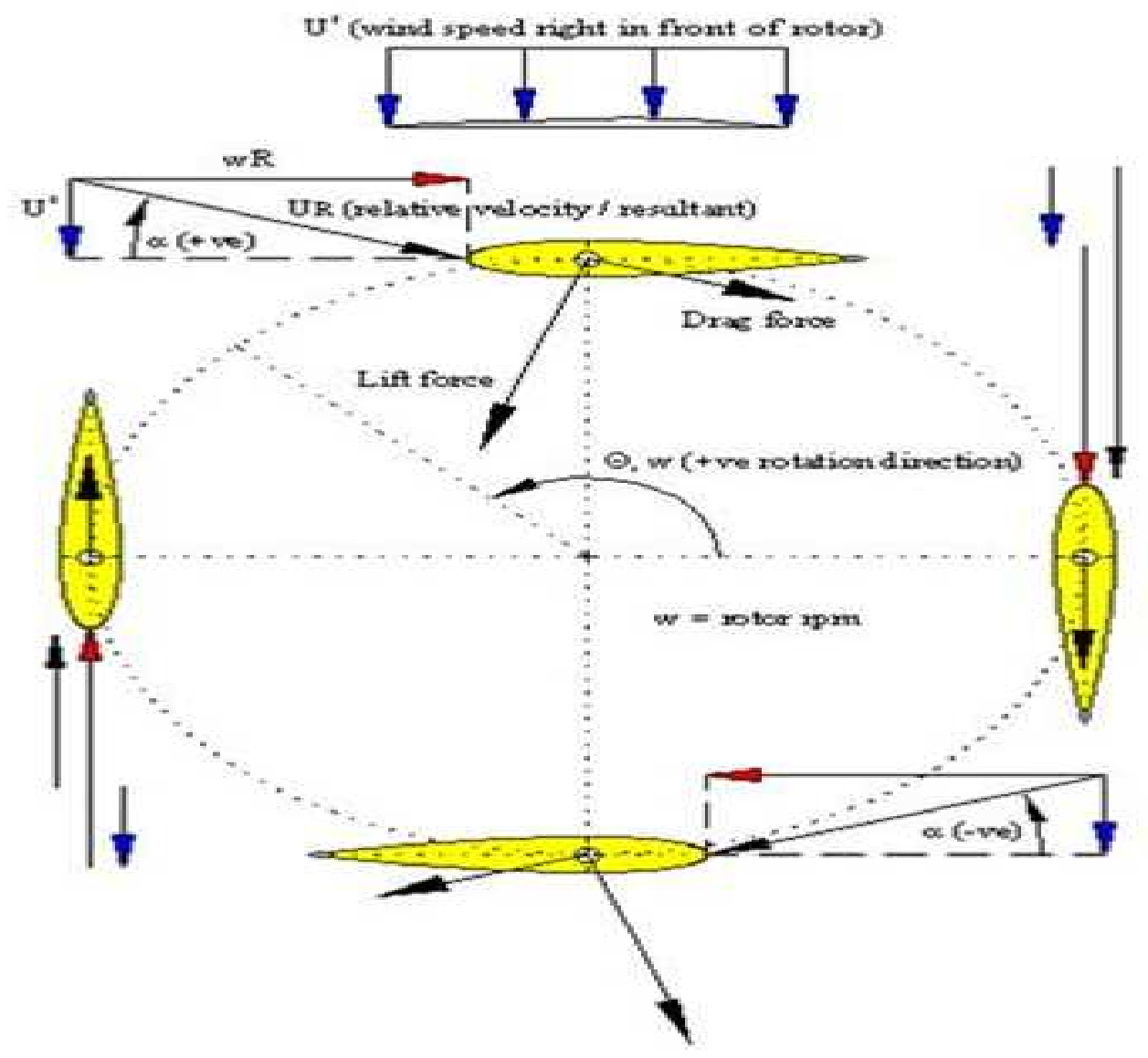

Gambar 2. Gaya-gaya pada setiap blade

Pada turbin Savonius gaya drag yang dihasilkan pada bagian cekung lebih besar, hal ini akan mempengaruhi torsi putaran Savonius. Rotor yang bekerja dibawah pengaruh gaya drag umumnya mempunyai torsi awal yang besar tetapi memiliki efisiensi yang lebih kecil bila dibandingkan dengan rotor yang bekerja dengan gaya lift. Karena keuntungan inilah banyak orang memanfaatkan sebagai penggerak awal dari turbin poros vertikal tipe lift seperti yang dilakukan oleh R. Gupta, R. Das dan K.K. Sharma dalam penelitiannya menggabungkan turbin Savonius-Darius [2] [9] [10].

\section{METODE PENELITIAN}

Tahap perancangan pembuatan turbin angin vertikal gabungan Savonius dan Darrieus menggunakan geometri Naca Airfoil 0018 [11] dapat dilihat dari Gambar 3. Sedangkan perancangan desain bilah turbin angin yang akan dilakukan seperti diperlihatkan pada gambar 4 adalah modifikasi turbin angin tipe Darrieus dengan geometry NACA Airfoil 0018 (warna merah) serta gabungan modofikasi turbin angin tipe Savonius (warna kuning) [12] [13] [14] [15] [16]. 


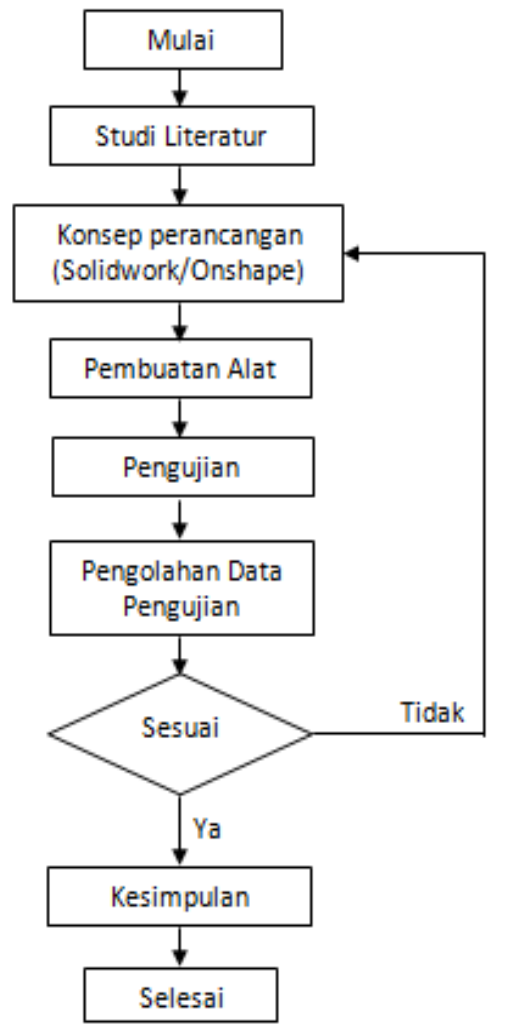

Gambar 3. Diagram alur perancangan

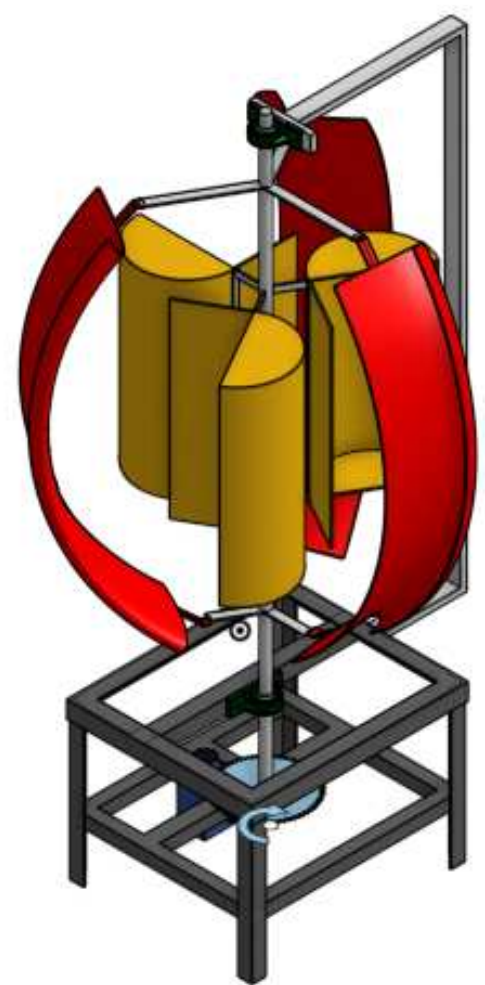

Gambar 4. Design Turbin Angin Vertikal Modifikasi Savonius dan Darrieus 
Berdasarkan gambar desain perancangan turbin angin modifikasi Savonius dan Darrieus, maka diperoleh dimensi perancangan yang diperlihatkan pada gambar 5 dan data hasil perncangan ditunjukkan pada tabel 1.
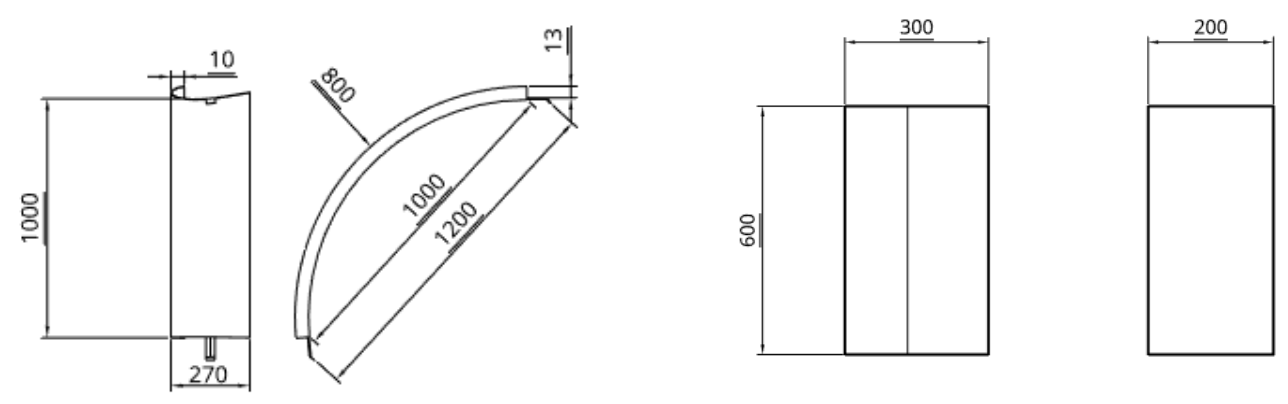

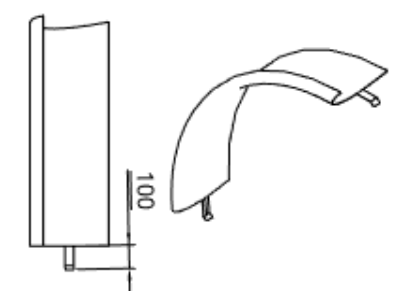

(a)

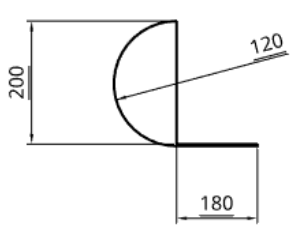

(b)

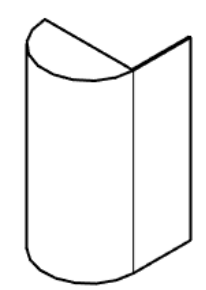

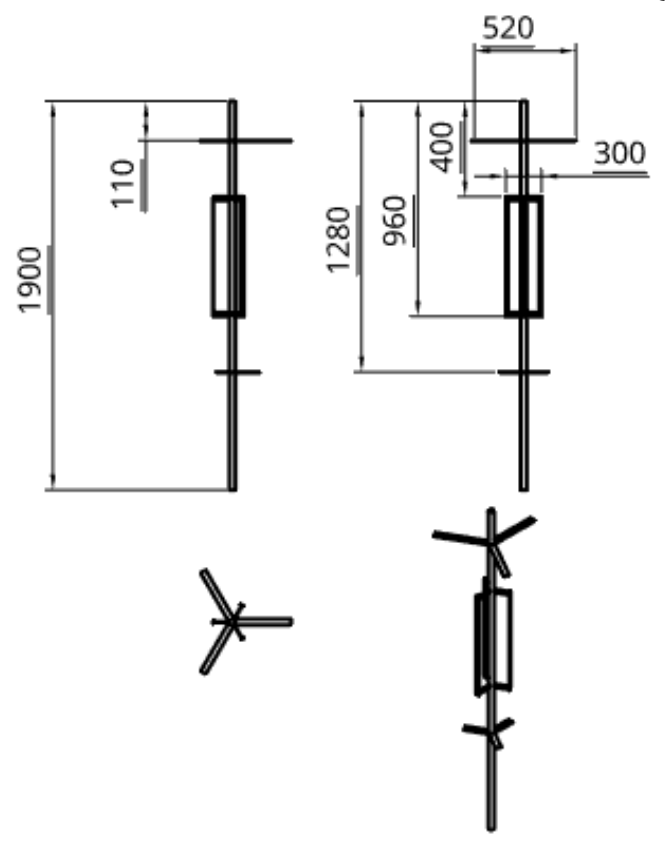

(c)

Gambar 5. (a) Blade modifikasi turbin angin tipe Darrieus, (b) blade modifikasi turbin angin tipe Savonius, (c) Poros penyangga 
Samosir, R., Perancangan Turbin Angin Vertikal Modifikasi Gabungan .....

Table 1. Data hasil perancangan

\begin{tabular}{lcccc}
\hline Jenis & $\begin{array}{c}\text { Jumlah blade } \\
\text { (unit) }\end{array}$ & $\begin{array}{c}\text { Panjang } \\
\text { lengan }(\mathrm{m})\end{array}$ & $\begin{array}{c}\text { Berat satu } \\
\text { buah Blade } \\
(\mathrm{kg})\end{array}$ & $\begin{array}{c}\text { Berat Total } \\
(\mathrm{kg})\end{array}$ \\
\hline Savonius & 3 & 0,12 & 0,7 & 2,1 \\
Darrieus & 3 & 0,12 & 1,4 & 4,2 \\
Aksesoris & & & & 0,2 \\
\hline Gabungan & 6 & & & 6,5 \\
\hline
\end{tabular}

\section{HASIL DAN PEMBAHASAN}

Berdasarkan data hasil perancangan dan pembuatan alat, maka dilakukan pengujian untuk turbin angin modifikasi Savonius, modifikasi Darrieus, dan modifikasi gabungan antara Savonius dan Darrieus. Hasil pengujian tersebut diperlihatkan pada tabel 2, 3, dan 4.

Table 2. Hasil pengujian turbin angin modifikasi Savonius

\begin{tabular}{cccccc}
\hline No. & $\begin{array}{c}\text { Kecepatan Angin } \\
(\mathrm{m} / \mathrm{s})\end{array}$ & $\begin{array}{c}\text { Putaran } \\
\text { Poros (rpm) }\end{array}$ & $\begin{array}{c}\text { Putaran } \\
\text { Generator } \\
(\mathrm{rpm})\end{array}$ & Tegangan (V) & Arus (A) \\
\hline 1 & 3 & 12,38 & 89,4 & 2,225 & 0,12 \\
2 & 4 & 14,5 & 104,7 & 3,725 & 0,24 \\
3 & 5,2 & 16,13 & 116,5 & 5,275 & 0,33 \\
4 & 6,1 & 19,25 & 139 & 6,75 & 0,49 \\
\hline
\end{tabular}

Table 3. Hasil pengujian turbin angin modifikasi Darrieus

\begin{tabular}{cccccc}
\hline No. & $\begin{array}{c}\text { Kecepatan Angin } \\
(\mathrm{m} / \mathrm{s})\end{array}$ & $\begin{array}{c}\text { Putaran } \\
\text { Poros (rpm) }\end{array}$ & $\begin{array}{c}\text { Putaran } \\
\text { Generator } \\
(\mathrm{rpm})\end{array}$ & Tegangan (V) & Arus (A) \\
\hline 1 & 3 & 19,2 & 138,7 & 6,7 & 0,43 \\
2 & 4 & 20,7 & 149,5 & 7,6 & 0,8 \\
3 & 5,2 & 21,9 & 158,2 & 8 & 0,8 \\
4 & 6,1 & 24,5 & 176,9 & 8,6 & 1,7 \\
\hline
\end{tabular}

Table 4. hasil pengujian turbin angin modifikasi gabungan Savonius dan Darrieus

\begin{tabular}{cccccc}
\hline No. & $\begin{array}{c}\text { Kecepatan Angin } \\
\text { (m/s) }\end{array}$ & $\begin{array}{c}\text { Putaran } \\
\text { Poros (rpm) }\end{array}$ & $\begin{array}{c}\text { Putaran } \\
\text { Generator } \\
\text { (rpm) }\end{array}$ & Tegangan (V) & Arus (A) \\
\hline 1 & 3 & 21,2 & 153,1 & 7,6 & 0,8 \\
2 & 4 & 23,6 & 170,4 & 8,3 & 1,3 \\
3 & 5,2 & 25,4 & 183,4 & 8,9 & 1,78 \\
4 & 6,1 & 27,6 & 199,3 & 9,4 & 1,9 \\
\hline
\end{tabular}

Dengan diperolehnya data hasil pengujian maka perhitungan setiap turbin angin dapat dilakukan sebagai berikut: 


\section{Perhitungan Turbin Angin}

Untuk memperoleh daya angin terlebih dahulu dihitung luas penampang turbin, sehingga daya angin pada kecepatan angin yang bervariasi dapat dihitung denggan menggunakan rumus $(\mathrm{Pa})=0,5 \times \rho \times \mathrm{A} \times \mathrm{v}^{3}$, sementara hasil yang diperoleh dari generator adalah berupa kuat arus dan voltase, maka daya angin perlu dikonversi dari generator dengan menggunakan rumus $\left(\mathrm{P}_{\text {gen }}\right)=$ Voltase $\times$ Ampere. Untuk memperoleh kemampuan turbin dalam mengkonversi daya angin dihitung berdasarkan perbandingan antara daya generator terhadap daya angin [17] [18] [19]. Data hasil perhitungan berdasarkan data hasil pengujian untuk turbin angina modifikasi Savonius, Darrieus, dan gabungan modifikasi Savonius dan Darrieus diperlihatkan pada tabel 5, 6, dan 7.

Table 5. Hasil perhitungan turbin angin modifikasi Savonius

\begin{tabular}{cccccccccc}
\hline $\begin{array}{c}\text { Kecepatan } \\
\text { Angin } \\
(\mathrm{m} / \mathrm{s})\end{array}$ & $\begin{array}{c}\text { Area } \\
\left(\mathrm{m}^{2}\right)\end{array}$ & $\begin{array}{c}\text { Putaran } \\
\text { Poros } \\
(\mathrm{rpm})\end{array}$ & $\begin{array}{c}\text { Putaran } \\
\text { Generator } \\
(\mathrm{rpm})\end{array}$ & $\begin{array}{c}\text { Tegangan } \\
(\mathrm{V})\end{array}$ & $\begin{array}{c}\text { Arus } \\
(\mathrm{A})\end{array}$ & $\begin{array}{c}\text { Daya } \\
\text { Angin } \\
\text { (Watt) }\end{array}$ & $\begin{array}{c}\text { Daya } \\
\text { Gener } \\
\text { ator } \\
(\text { Watt })\end{array}$ & TSR & $\mathrm{C}_{\mathrm{p}}(\%)$ \\
\hline 3 & 0,68 & 12,38 & 89,4 & 2,225 & 0,12 & 11,1 & 0,26 & 0,15 & 0,024 \\
4 & 0,68 & 14,5 & 104,7 & 3,725 & 0,24 & 26,27 & 0,9 & 0,13 & 0,034 \\
5,2 & 0,68 & 16,13 & 116,5 & 5,275 & 0,33 & 57,71 & 1,74 & 0,11 & 0,03 \\
6,1 & 0,68 & 19,25 & 139,0 & 6,75 & 0,49 & 93,15 & 3,32 & 0,12 & 0,041 \\
\hline
\end{tabular}

Table 6. Hasil perhitungan turbin angin Darrieus

\begin{tabular}{cccccccccc}
\hline $\begin{array}{c}\text { Kecepatan } \\
\begin{array}{c}\text { Angin } \\
(\mathrm{m} / \mathrm{s})\end{array}\end{array}$ & $\begin{array}{c}\text { Area } \\
\left(\mathrm{m}^{2}\right)\end{array}$ & $\begin{array}{c}\text { Putaran } \\
\text { Poros } \\
(\mathrm{rpm})\end{array}$ & $\begin{array}{c}\text { Putaran } \\
\text { Generator } \\
(\mathrm{rpm})\end{array}$ & $\begin{array}{c}\text { Tegangan } \\
(\mathrm{V})\end{array}$ & $\begin{array}{c}\text { Arus } \\
(\mathrm{A})\end{array}$ & $\begin{array}{c}\text { Daya } \\
\text { Angin } \\
(\text { Watt })\end{array}$ & $\begin{array}{c}\text { Daya } \\
\text { Generator } \\
(\text { Watt })\end{array}$ & $\begin{array}{c}\text { TSR } \\
(\%)\end{array}$ & $\begin{array}{c}\mathrm{C}_{\mathrm{p}} \\
(\%)\end{array}$ \\
\hline 3 & 0,99 & 19,2 & 138,7 & 6,7 & 0,43 & 16,04 & 2,88 & 0,4 & 0,18 \\
4 & 0,99 & 20,7 & 149,5 & 7,6 & 0,8 & 38,02 & 6,08 & 0,32 & 0,16 \\
5,2 & 0,99 & 21,9 & 158,2 & 8 & 1,2 & 83,52 & 9,6 & 0,26 & 0,12 \\
6,1 & 0,99 & 24,5 & 176,9 & 8,6 & 1,7 & 134,83 & 14,62 & 0,25 & 0,11 \\
\hline
\end{tabular}

Table 7. Hasil perhitungan turbin angin gabungan modifikasi Savonius dan Darrieus

\begin{tabular}{|c|c|c|c|c|c|c|c|c|c|}
\hline $\begin{array}{l}\text { Kecepatan } \\
\text { Angin } \\
(\mathrm{m} / \mathrm{s})\end{array}$ & $\begin{array}{l}\text { Area } \\
\left(\mathrm{m}^{2}\right)\end{array}$ & $\begin{array}{l}\text { Putaran } \\
\text { Poros } \\
\text { (rpm) }\end{array}$ & $\begin{array}{l}\text { Putaran } \\
\text { Generator } \\
\text { (rpm) }\end{array}$ & $\begin{array}{l}\text { Tegangan } \\
\text { (V) }\end{array}$ & $\begin{array}{l}\text { Arus } \\
(\mathrm{A})\end{array}$ & $\begin{array}{l}\text { Daya } \\
\text { Angin } \\
\text { (Watt) }\end{array}$ & $\begin{array}{c}\text { Daya } \\
\text { Generator } \\
\text { (Watt) }\end{array}$ & TSR & $\begin{array}{c}\mathrm{C}_{\mathrm{p}} \\
(\%)\end{array}$ \\
\hline 3 & 1,67 & 21,2 & 153,1 & 7,6 & 0,8 & 20,75 & 6,08 & 0,44 & 0,23 \\
\hline 4 & 1,67 & 23,6 & 170,4 & 8,3 & 1,3 & 64,13 & 10,79 & 0,37 & 0,17 \\
\hline 5,2 & 1,67 & 25,4 & 183,4 & 8,9 & 1,78 & 140,89 & 15,84 & 0,31 & 0,11 \\
\hline 6,1 & 1,67 & 27,6 & 199,3 & 9,4 & 1,9 & 227,4 & 17,86 & 0,28 & 0,08 \\
\hline
\end{tabular}

Berdasarkan hasil perhitungan tersebut, kita dapat membandingkan hasil antara savonius, Darrieus dan gabungan Savonius - Darrieus seperti ditunjukkan pada gambar 6. Lebih lanjut, hasil perbandingan antara kecepatan angin dan coefficient power pada turbin angin jenis modifikasi savonius, Darrieus dan gabungan Savonius - Darrieus ditunjukkan pada gambar 7 . 
Samosir, R., Perancangan Turbin Angin Vertikal Modifikasi Gabungan .....

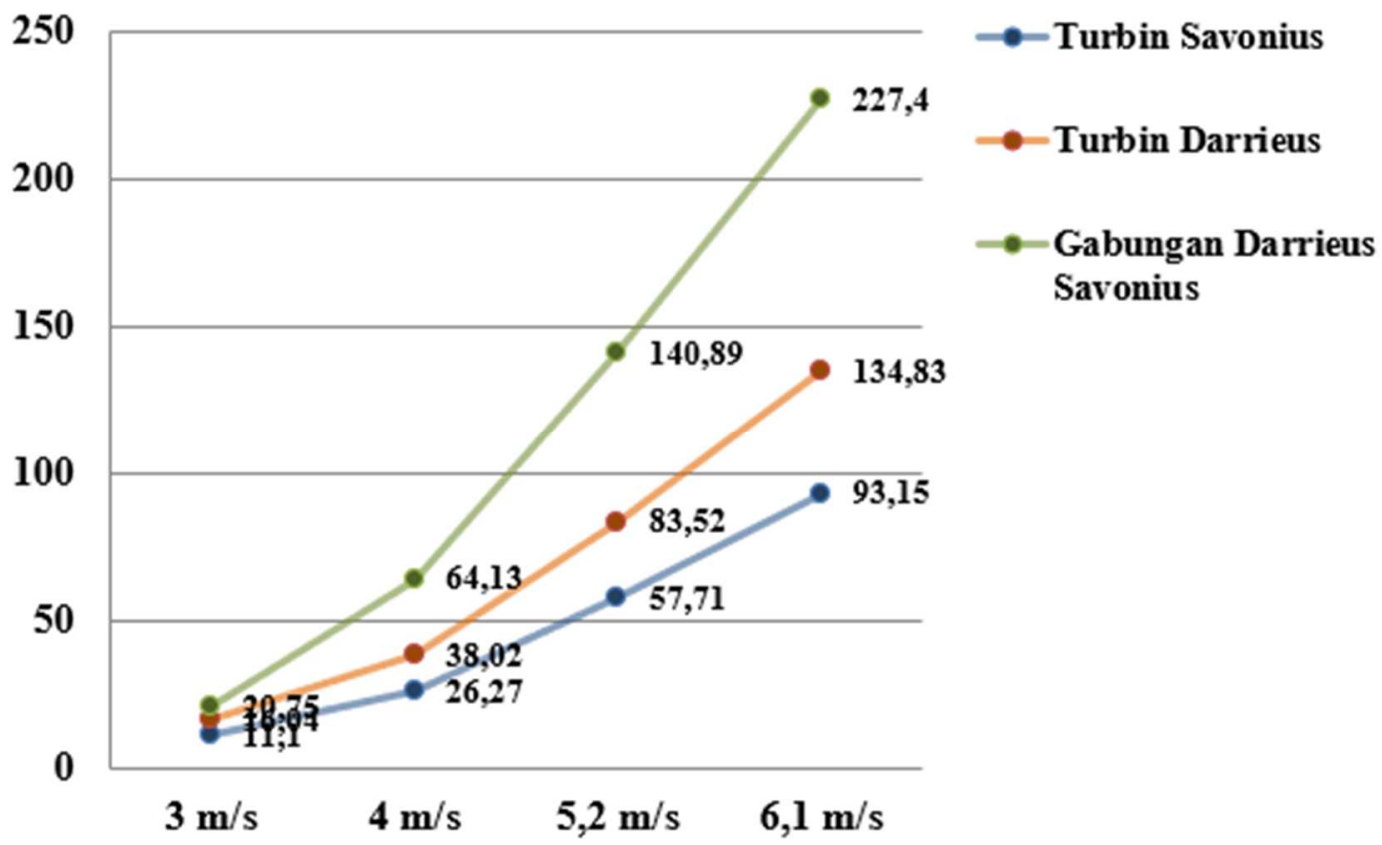

Gambar 6. Grafik kecepatan angin VS daya angin

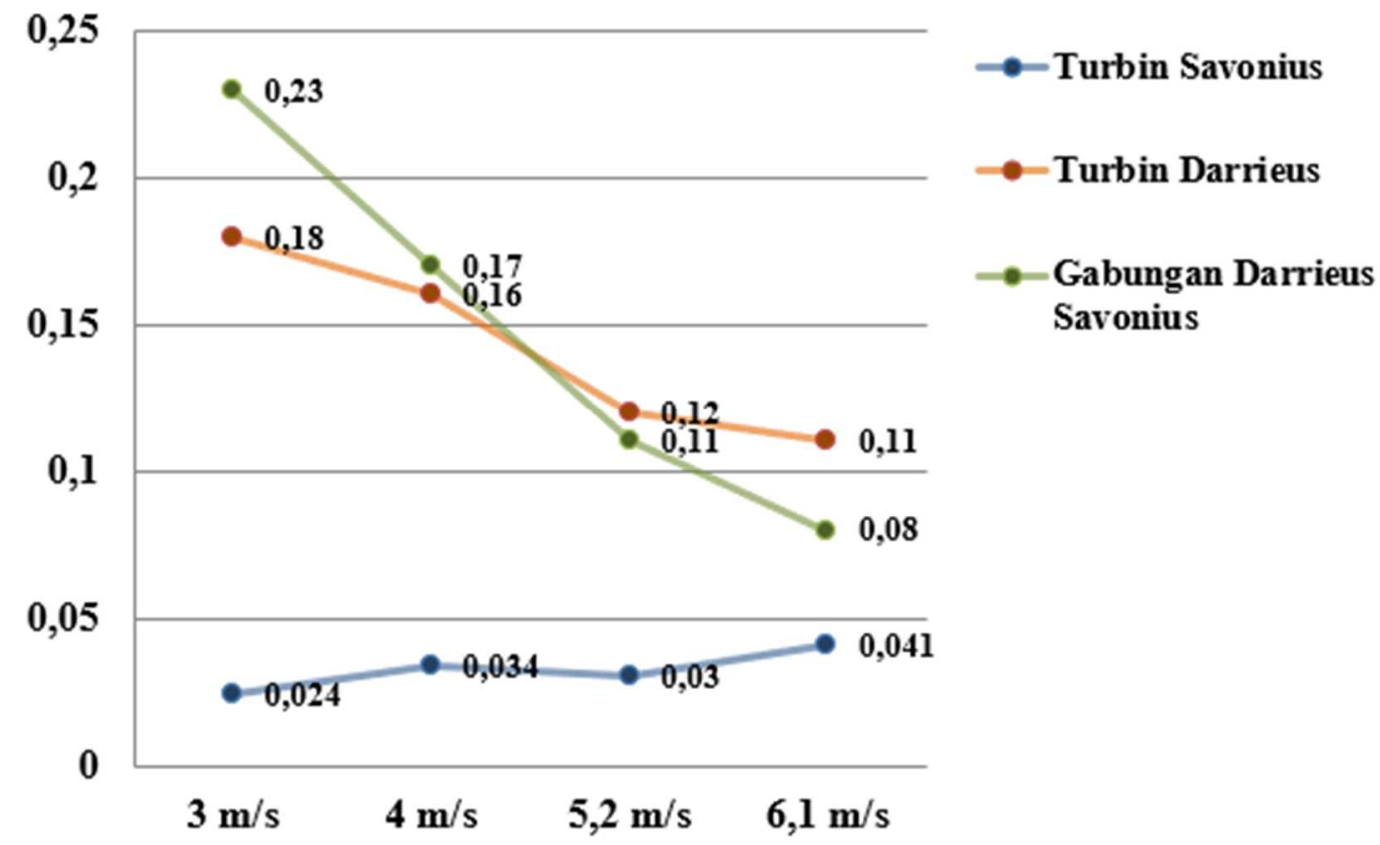

Gambar 7. Grafik kecepatan angin VS coefficient power

\section{KESIMPULAN}

Berdasarkan dari hasil perhitungan yang diperoleh dapat disimpulkan bahwa daya output turbin angin gabungan lebih besar dibandingkan turbin angin Savonius dan Darrieus yaitu turbin angin gabungan 12,46 kali lebih besar dari turbin Savonis, dan 1,69 kali lebih besar dari turbin Darieus. 


\section{REFERENSI}

[1] W. Tong, Wind Power Generation and Wind Turbine Design, Massachusetts: WIT Press, 2010.

[2] D. A. Spera, Wind Turbine Technology: Fundamental Concepts of Wind Turbine Engineering, New York: ASME Press, 2009.

[3] I. Paraschivoiu, Wind Turbine Design: With Emphasis on Darrieus Concept, Montreal: Presses inter Polytechnique, 2002.

[4] A. Kalmikov and K. Dykes, "Wind Power Fundamentals," in Renewable Energy Projects, Massachusetts, 2010.

[5] R. C. SUBEKTI and I. H. SIREGAR, "STUDI EXPERIMENTAL TURBIN ANGIN SAVONIUS TIPE C SATU TINGKAT DENGAN PENAMBAHAN FIX DRAG REDUCING PADA BLADE," Jurnal Pendidikan Teknik Mesin, vol. 8, no. 3, pp. 15-24, 2019.

[6] J. Shi and E. Erdem, "Estimation of Wind Energy Potential and Prediction of Wind Power," in Wind Energy Engineering, Cincinnati, Academic Press, 2017, pp. 25-49.

[7] D. Darianto, B. Umroh, A. Amrinsyah and A. J. Zulfikar, "Numerical Simulation on Mechanical Strength of a Wooden Golf Stick," JMEMME (Journal Of Mechanical Engineering, Manufactures, Materials And Energy), vol. 2, no. 1, p. 13-19, 2018.

[8] I. Ismail, E. Pane and T. Triyanti, "OPTIMASI PERANCANGAN TURBIN ANGIN VERTIKAL TIPE DARRIEUS UNTUK PENERANGAN DI JALAN TOL," in Seminar Nasional Sains dan Teknologi, Jakarta, 2017.

[9] E. . E. K. Widodo, "Unjuk kerja turbin angin Darrieus tipe H berpenampang sudu NACA Seri 2415 dengan tiga variasi diameter," USD Repository, Jogjakarta, 2019.

[10] D. P. Teja, "Studi numerik turbin angin Darrieus - Savonius dengan penambahan stage rotor Darrieus," ITS Repository, Surabaya, 2017.

[11] Y. C. Prastiko, "Uji kinerja trubin angin sumbu vertikal tipe-H NACA oo18 modifikasi dengan variasi sudut pitch 35 derajat, 40 derajat, 45 derajat, 50 derajat, 55 derajat," UMS Press, Surakarta, 2016.

[12] M. Y. Yuhazri, A. J. Zulfikar and A. Ginting, "Fiber Reinforced Polymer Composite as a Strengthening of Concrete Structures: A Review," in 2nd International Conference in Industry and Manufacture Engineerin, Medan, 2020.

[13] A. J. Zulfikar, B. Umroh and M. Y. Siahaan, "Investigation of Mechanical Behavior of Polymeric Foam Materials Reinforced by Oil Palm Empty Fruit Bunches (OPEFB) Fibers Due to Static and Dynamic Loads," JMEMME, vol. 3, no. 1, pp. 10-19, 2019.

[14] A. J. Zulfikar, "The Flexural Strength of Artificial Laminate Composite Boards made from Banana Stems," Budapest International Research in Exact Sciences (BirEx) Journal, vol. 2, no. 3, pp. 334340, 2020.

[15] A. J. Zulfikar, A. Sofyan and M. Y. Siahaan, "Numerical Simulation on The Onion Dryer Frame Capacity of $5 \mathrm{~kg} /$ hour," JMEMME (Journal of Mechanical Engineering Manufactures Materials and Energy), vol. 2, no. 2, p. 86-92, 2018.

[16] "NACA 4 digit airfoil generator (NACA 2412 AIRFOIL)," Airfoil Tools, o1 o1 2018. [Online]. Available: http://airfoiltools.com/airfoil/naca4digit. [Accessed 0505 2020].

[17] R. Taufiqurrahman and V. Suphandani, "Studi Numerik Turbin Angin Darrieus dengan Variasi Jumlah Sudu dan Kecepatan Angin," Jurnal Teknik ITS, vol. 6, no. 1, pp. 13-18, 2017.

[18] A. J. Zulfikar, B. Umroh, A. Amrinsyah and F. A. Nasution, "Numerical Analysis of Strength of Rear Brake Holder Flat on The Motor," JMEMME (Journal Of Mechanical Engineering, Manufactures, Materials And, vol. 2, no. 1, pp. 1-6, 2018.

[19] F. Aryanto, I. M. Mara and M. Nuarsa, "PENGARUH KECEPATAN ANGIN DAN VARIASI JUMLAH SUDU TERHADAP UNJUK KERJA TURBIN ANGIN POROS HORIZONTAL," Dinamika Teknik Mesin, vol. 3, no. 1, pp. 50-59, 2013. 